\title{
REACTION OF Psidium spp. ACCESSIONS TO DIFFERENT LEVELS OF INOCULATION WITH Meloidogyne enterolobii ${ }^{1}$
}

\author{
PATRÍCIA GOMES DE OLIVEIRA ${ }^{*}$, MANOEL ABILIO DE QUEIRÓZ ${ }^{3}$, JOSÉ MAURO DA CUNHA E CASTRO $^{4}$, JULIANA \\ MARTINS RIBEIRO ${ }^{4}$, RONALDO SIMÃO DE OLIVEIRA ${ }^{5}$, MARIA JOSÉ LIMA DA SILVA ${ }^{6}$
}

\begin{abstract}
Meloidogyne enterolobii associated with Fusarium solani causes the guava decay, which is the main factor of yield loss in guava crops and limits guava production in Brazil. Therefore, searching for guava genotypes (Psidium spp.) with resistance to M. enterolobii is important to control this root-knot nematode. The objective of the present work was to evaluate the reaction of Psidium spp. accessions from the Germplasm Bank of the Bahia State University (UNEB) to different levels of inoculation with M. enterolobii. Guava seedlings were inoculated with $600,1,600$, and 2,000 eggs $+\mathrm{J} 2$ second stage juveniles of $M$. enterolobii and the root fresh weight, total number of eggs (TNE), and reproduction factor (RF) were evaluated. The results were subjected to ANOVA and means were clustered using the Scott-Knott test at 5\% probability. The diversity of accessions was estimated using the Tocher's clustering and UPGMA methods. The nematode RF reduced in some accessions with increasing inoculation levels of the nematode. However, the RF increased in some accessions with high levels of inoculation. Plants of the Y50 accession were immune or resistant to $M$. enterolobii, indicating variability of reaction of plants to the nematode within the Psidium genus. The resistance of Psidium accessions to $M$. enterolobii needs to be measured with different inoculation levels to verify the existence of false-positive results, since the evaluated accessions, including the Paluma cultivar, presented distinct reactions regarding $\mathrm{RF}$ in the three levels of inoculation used.
\end{abstract}

Keywords: Guava. Root-knot nematode. Genetic variability.

\section{REAÇÃO DE ACESSOS DE Psidium spp. A DIFERENTES NÍVEIS DE INÓCULO DE Meloidogyne enterolobii}

RESUMO - Meloidogyne enterolobii, juntamente com Fusarium solani, causam o declínio da goiabeira que é a principal causa de perdas na produção de goiaba, limitando o cultivo em todo o Brasil. Portanto, a busca por genótipos dentro do gênero Psidium com resistência a $M$. enterolobii é muito importante para o controle deste nematoide. Assim, o presente trabalho teve como objetivo avaliar a reação de acessos de Psidium spp., pertencentes ao Banco de Germoplasma da Universidade do Estado da Bahia (UNEB), a diferentes níveis de inóculo de $M$. enterolobii. Mudas de goiabeira foram inoculadas com 600, 1.600 e 2.000 ovos $+\mathrm{J} 2$ (juvenis de segundo estádio)de $M$. enterolobii/planta e avaliados a massa fresca de raízes, o número total de ovos (NTO) e o fator de reprodução (FR). A análise de variância foi feita e o agrupamento de médias foi realizado pelo teste Scott-Knott a $5 \%$ de probabilidade. A diversidade dos acessos foi estimada pelo agrupamento de Tocher e UPGMA. O FR do nematoide apresentou redução em alguns acessos à medida que os níveis de inóculo aumentaram, contudo, em alguns acessos, nos maiores níveis, o FR aumentou. O acesso Y50 teve plantas imunes e resistentes a $M$. enterolobii, demostrando que ocorre variabilidade na reação ao nematoide dentro do gênero Psidium. A resistência de acessos de Psidium a $M$. enterolobii deve ser mensurada em diferentes níveis de inóculo de modo a permitir avaliar a existência de falsos-positivos nesses acessos uma vez que há reação distinta dos acessos avaliados quanto à reprodução do nematoide nos três níveis de inóculo usados, inclusive na cv. Paluma.

Palavras-chave: Goiaba. Nematoide-das-galhas. Variabilidade genética.

\footnotetext{
${ }^{*}$ Corresponding author

${ }^{1}$ Received for publication in $11 / 04 / 2017$; accepted in $02 / 21 / 2019$.

Paper extracted from the author's master dissertation.

${ }^{2}$ Department of Biological Sciences, Universidade Estadual de Feira de Santana, Feira de Santana, BA, Brazil; pati.24gomes@gmail.com ORCID: 0000-0002-8232-824X.

${ }^{3}$ Departament of Social Sciences and Technology, Universidade do Estado da Bahia, Juazeiro, BA, Brazil; manoelabiliomaq@gmail.com ORCID: 0000-0001-9501-2343.

${ }^{4}$ Embrapa Semiárido, Petrolina, PE, Brazil; mauro.castro@embrapa.br - ORCID: 0000-0003-1345-6042, juliana.ribeiro@embrapa.br ORCID: 0000-0002-3098-9396.

${ }^{5}$ Instituto Federal de Ciência e Tecnologia, Xique Xique, BA, Brazil; ronaldosimaorso@gmail.com - ORCID: 0000-0003-0996-9144.

${ }^{6}$ Universidade de Pernambuco, Petrolina, PE, Brazil; m4r14-limasilva@outlook.com - ORCID: 0000-0001-5083-2516.
} 


\section{INTRODUCTION}

Psidium guajava L. (guava) is the most important species of the Psidium genus; it is widely grown and adapted to tropical and subtropical climates (FRANZON, 2009). The fruits produced by this species have high commercial value, are rich in minerals and vitamin $\mathrm{C}$, contains several medicinal active ingredients (PEREIRA; NACHTIGAL, 2000; AMAYA; FARFAN, 2009; MARQUES et al., 2016), and is used to produce jams and jellies (MANICA et al., 2000; SÃO JOSÉ et al., 2003). The Brazilian guava production in 2015 was $424,305 \mathrm{Mg}$; the Northeast region of Brazil produced 207,169 Mg, mainly in the states of Pernambuco and Bahia (AGRIANUAL, 2018).

The guava crop has the highest economical value among Psidum species; however, this genus has other wild species, known in Brazil as araçá trees, such as $P$. guineense Swart, $P$. shenckianum Kiarsk, and $P$. cattleianum Sabine; these species produce edible fruits with exotic flavor and high concentrations of vitamin $\mathrm{C}$, which can be consumed fresh or processed (jams or jellies) and have raised the interest of pharmaceutical industries because of their high potential for economic exploitation (FRANZON, 2009; SANTOS et al., 2014). Araçá species are widely distributed in Brazil (FRANZON, 2009); P. schenckianum Kiarsk, $P$. guineense, and $P$. grandifolium Mart were found in the Bahia semiarid region (SANTOS et al., 2014); these species were sampled, and currently form a collection of about 100 accessions belonging to the Bahia State University (UNEB), in Juazeiro, BA, Brazil.

Studies have been conducted using different methodologies and criteria to classify accessions of Psidium spp. as resistant or susceptible to Meloidogyne enterolobii Yang \& Eisenback. This nematode is the main cause of losses in guava crops, limiting guava production in Brazil (PEREIRA et al., 2016). In addition, $M$. enterolobii infection is associated with soil fungi (GOMES et al., 2011), leading to a synergistic interaction that causes even greater damage to crops (GOMES et al., 2017; CASTRO et al., 2017).

Some wild Psidium species are hosts of $M$. enterolobii, and others present resistance or immunity to it (MIRANDA et al., 2012; MARTINS et al., 2013; PEREIRA et al., 2016). However, these accessions are usually evaluated using only one level (often high) of inoculation (BURLA et al., 2010). Miranda et al. (2010) used 500 eggs per plant and two different methodologies (OOSTENBRINK, 1966; MOURA; RÉGIS, 1987) to evaluate the reproduction factor of $M$. enterolobii in 26 Psidium spp. accessions and found a greater number of susceptible accessions. However, Carneiro et al. (2007) found resistance in P. friedrichsthalianum (O. Berg) Nied and in P. cattleianum Sabine inoculated with 10,000 eggs of $M$. enterolobii per plant; and Martins et al. (2013) inoculated Psidium spp. with 20,000 eggs, divided into two inoculations of 10,000 eggs per plant with a 30-day interval, and found five resistant and eight susceptible accessions to $M$. enterolobii.

The objective of the present work was to evaluate the reaction of Psidium spp. accessionsfrom the Germplasm Bank of the UNEB-to different levels of inoculation of $M$. enterolobii.

\section{MATERIAL AND METHODS}

The study was conducted at the State University of Feira de Santana (Feira de Santana, BA, Brazil) in partnership with the Brazilian Agricultural Research Corporation (Embrapa Semiarid, Petrolina, PE, Brazil). Twelve accessions of Psidium spp. were used (Table 1). The Paluma cultivar (Psidium guajava), which is a known susceptible cultivar to $M$. enterolobii, was used to evaluate the inoculum quality and to compare the results (GOMES et al., 2017). The experiment was conducted in a completely randomized design with eight replications for each accession.

Seedlings were obtained from seeds, because of difficulties of vegetative propagation through rooting of cuttings of wild Psidium spp. Seeds of Psidium spp. from the Active Germplasm Bank of the UNEB, Campus III (Juazeiro, BA, Brazil), were sowed in pots with a diameter of $10.5 \mathrm{~cm}$, containing a vermiculite-based substrate that is used for vegetable production. The pots were kept in a greenhouse after sowing, and the emergence of seedlings occurred between 30 and 40 days after sowing. When the seedlings had three to six leaves, they were transplanted to 3 -liter pots containing autoclaved $\left(120^{\circ} \mathrm{C}\right.$ for 50 minutes) sandy soil.

The M. enterolobii inoculum was obtained from a pure population maintained in Santa Cruz tomatoes of the Kada cultivar, in a greenhouse of the Embrapa Semiarid. The M. enterolobii inoculum was prepared following the methodology used by Boneti and Ferraz (1981). The suspension was calibrated using Peters' slides under an optical microscope, for inoculations with $600,1,600$, and 2,000 eggs $+\mathrm{J} 2$ per plant, according to the treatments. Inoculation was carried out five days after transplanting; the suspension with eggs $+\mathrm{J} 2$ was equally distributed in two holes near the plant root system. The plants were fertilized with ammonium sulphate, single superphosphate, and potassium chloride formulations at 30 and 90 days after inoculation; they were manually irrigated daily during the experimental period.

The plants were removed from the pots 135 days after inoculation; their roots were washed and weighed to evaluate their total fresh root weight. Ten grams of roots of each plant were used to egg 
extraction (Boneti and Ferraz, 1981). Eggs counting was performed on Peters' slides under an optical microscope. The reproduction factor (RF) was determined by the equation $[R F=P f / P i]$, wherein $P f$ is the final population and $P i$ is the initial population $(P i=600,1,600$, or 2,000 eggs $+\mathrm{J} 2)$. Psidium spp. with $\mathrm{RF}<1$ were resistant and those with RF $>1$ were susceptible (OOSTENBRINK, 1966).

The results of root fresh weight and RF were transformed to $\log (\mathrm{x}+1)$, and the number of eggs to $\log (x+0.5)$. After analysis of variance, the data were subjected to clustering by the Scott-Knott test at $5 \%$ probability.

The diversity among accessions was estimated through univariate analysis, followed by multivariate analysis through the Tocher's clustering method (CRUZ, 2013). The clustering analysis by the UPGMA (unweighted pair group method with arithmetic mean) method was performed using the dissimilarity matrix, and the cut-off point was based on the method used by Mojena (1977).

The cophenetic correlation coefficient (CCC) was estimated to validate the groups generated by the UPGMA method, using the Pearson correlation coefficient considering the distance matrix and the cophenetic matrix of distance among the accessions (CRUZ; REGAZZI; CARNEIRO, 2012). The data were subjected to ANOVA, and the variance was estimated within and between accessions. The data were analyzed using the Genes program (CRUZ, 2013).

Table 1. Data of Psidium spp. from the active Germplasm Bank of the Bahia State University (UNEB), Campus III, Juazeiro, BA, Brazil.

\begin{tabular}{|c|c|c|c|c|}
\hline Accession & Species & Place of collection & Geographical Coordinates & $\begin{array}{l}\text { Altitude } \\
(\mathrm{m})\end{array}$ \\
\hline Y81 & P. guineense & Campo Formoso - BA & $10^{\circ} 29^{\prime} 19.0^{\prime \prime S} 40^{\circ} 17^{\prime} 16.7^{\prime \prime} \mathrm{W}$ & 692 \\
\hline Y48 & P. guineense & Campo Formoso - BA & $10^{\circ} 36^{\prime} 73.3^{\prime \prime} \mathrm{S} 40^{\circ} 26^{\prime} 85.8^{\prime \prime} \mathrm{W}$ & 889 \\
\hline Y105 & Psidium sp. & Uauá - BA & - & - \\
\hline $\mathrm{Y} 40$ & P. guineense & Campo Formoso - BA & $10^{\circ} 29^{\prime} 18.9^{\prime \prime} \mathrm{S} 40^{\circ} 17^{\prime} 16.5^{\prime \prime} \mathrm{W}$ & 683 \\
\hline Y92 & P. guineense & Campo Formoso - BA & $10^{\circ} 36^{\prime} 39.5^{\prime \prime S} 40^{\circ} 26^{\prime} 49.8^{\prime \prime} \mathrm{W}$ & 873 \\
\hline Y46 & $P$. guineense & Campo Formoso - BA & $10^{\circ} 36^{\prime} 72.5^{\prime \prime S} 40^{\circ} 26^{\prime} 84.8^{\prime \prime} \mathrm{W}$ & 882 \\
\hline Y91 & P. guineense & Campo Formoso - BA & $10^{\circ} 29^{\prime} 15.5^{\prime \prime S} 40^{\circ} 17^{\prime} 23.9^{\prime \prime} \mathrm{W}$ & 661 \\
\hline Y10 & P. schenckianum & Uauá - BA & $09^{\circ} 42^{\prime} 46.7^{\prime \prime S} 39^{\circ} 38^{\prime} 25.5^{\prime \prime} \mathrm{W}$ & 679 \\
\hline Y80 & Psidium sp. & Bezerros - PE & - & - \\
\hline Y62 & Psidium $\mathrm{sp}$. & Jacobina - BA & - & - \\
\hline Y93 & P. guineense & Senhor do Bonfim - BA & $10^{\circ} 21^{\prime} 33.8^{\prime \prime S} 40^{\circ} 09^{\prime} 58.9^{\prime \prime} \mathrm{W}$ & 535 \\
\hline Y50 & Psidium sp. & Uauá - BA & - & 528 \\
\hline PALUMA & P. guajava & - & - & - \\
\hline
\end{tabular}

- data not available.

\section{RESULTS AND DISCUSSION}

The accessions and inoculation levels presented significant differences for the three analyzed variables. However, the interaction between accessions and inoculation levels was significant only for root fresh weight and number of eggs. The coefficient of variation for root fresh weight and reproduction factor (RF) was high, indicating a variation between plants of the same accession (Table 2).

Table 2. Analysis of variance for root fresh weight (RFW), total number of eggs (TNE), and reproduction factor (RF) found in evaluations of Psidium spp. accessions under different inoculation levels of Meloidogyne enterolobii.

\begin{tabular}{|c|c|c|c|c|}
\hline \multirow{2}{*}{ Source of variation } & \multirow{2}{*}{$\begin{array}{c}\text { Degrees of } \\
\text { Freedom }\end{array}$} & \multicolumn{2}{|c|}{ Mean squares } & \multirow[b]{2}{*}{$\mathrm{RF}$} \\
\hline & & RFW & $\mathrm{TNE}$ & \\
\hline Accessions (A) & 12 & $0.69^{* *}$ & $8.54^{* *}$ & $2.61^{* *}$ \\
\hline Inoculation level (I) & 2 & $0.073^{* *}$ & $0.45^{* *}$ & $5.03^{* *}$ \\
\hline $\mathrm{A} \times \mathrm{I}$ & 24 & $0.021^{* *}$ & $0.27^{* *}$ & $0.21^{\mathrm{NS}}$ \\
\hline Residue & 260 & 0.11 & 0.15 & 0.11 \\
\hline CV (\%) & & 28.59 & 9.41 & 27.88 \\
\hline
\end{tabular}

$* *=$ significant at $5 \%$ probability; $\mathrm{NS}=$ not significant at $5 \%$ probability. 
Three groups of means were formed for the three variables analyzed in the three inoculation levels, except for root fresh weight at the inoculation level of 2,000 eggs $+\mathrm{J} 2$, which formed only two groups. The total number of eggs formed two groups for the different inoculation levels, in which only the Y93 and Y50 accessions had significant difference at the highest inoculation level (Table 3). The reproduction factor formed three groups for the inoculation levels of 600 and 2,000 eggs $+\mathrm{J} 2$, and two groups for the inoculation level of 1,600 eggs +
J2. The evaluated inoculation levels formed three groups of means, with no significant differences for Y81, Y92, 'Paluma', and Y10 (Table 3).

Root fresh weight presented significantly variation among and within for inoculation levels and accessions (Table 3); different results were found by Burla et al. (2010), who found no effect of the inoculation level on this variable. However, root fresh weight is important to determine, for example, the number of eggs per gram of root.

Table 3. Clustering of means of root fresh weight (RFW), total number of eggs (TNE), and reproduction factor (RF) found in evaluations of Psidium spp. accessions under different inoculation levels of Meloidogyne enterolobii.

\begin{tabular}{cccccccccc}
\hline & \multicolumn{3}{c}{ RFW } & \multicolumn{9}{c}{ TNE } & \multicolumn{3}{c}{ RF } \\
\hline Accession & & & \multicolumn{9}{c}{ Initial inoculation level (eggs $+\mathrm{J} 2)$} \\
\hline & 600 & 1,600 & 2,000 & 600 & 1,600 & 2,000 & 600 & 1,600 & 2,000 \\
\hline Y81 & $5.02 \mathrm{aA}$ & $5.23 \mathrm{aA}$ & $5.03 \mathrm{aA}$ & $15.175 \mathrm{bA}$ & $30.664 \mathrm{bA}$ & $20.625 \mathrm{bA}$ & $13.54 \mathrm{cA}$ & $19.07 \mathrm{bA}$ & $10.85 \mathrm{cA}$ \\
Y48 & $4.04 \mathrm{aA}$ & $4.38 \mathrm{bA}$ & $4.12 \mathrm{aA}$ & $29.025 \mathrm{bA}$ & $14.400 \mathrm{bA}$ & $16.275 \mathrm{bA}$ & $48.34 \mathrm{bA}$ & $10.40 \mathrm{bB}$ & $16.89 \mathrm{bB}$ \\
Y92 & $3.80 \mathrm{aA}$ & $3.97 \mathrm{bA}$ & $3.38 \mathrm{aA}$ & $20.281 \mathrm{aA}$ & $26.918 \mathrm{bA}$ & $30.106 \mathrm{aA}$ & $33.80 \mathrm{bA}$ & $16.82 \mathrm{bA}$ & $15.88 \mathrm{bA}$ \\
Y105 & $0.93 \mathrm{cA}$ & $1.04 \mathrm{cA}$ & $1.30 \mathrm{bA}$ & $10.187 \mathrm{bA}$ & $13.731 \mathrm{bA}$ & $18.243 \mathrm{bA}$ & $18.10 \mathrm{cA}$ & $8.57 \mathrm{bB}$ & $7.24 \mathrm{cB}$ \\
Y40 & $3.15 \mathrm{aB}$ & $3.96 \mathrm{bA}$ & $3.95 \mathrm{aA}$ & $31.687 \mathrm{aA}$ & $32.250 \mathrm{bA}$ & $28.425 \mathrm{aA}$ & $52.85 \mathrm{bA}$ & $20.14 \mathrm{bB}$ & $14.21 \mathrm{bB}$ \\
Y46 & $5.83 \mathrm{aA}$ & $7.03 \mathrm{aA}$ & $4.73 \mathrm{aA}$ & $50.612 \mathrm{aA}$ & $83.012 \mathrm{aA}$ & $28.725 \mathrm{aA}$ & $83.52 \mathrm{aA}$ & $52.20 \mathrm{aB}$ & $14.26 \mathrm{bB}$ \\
'Paluma' & $4.36 \mathrm{aA}$ & $6.80 \mathrm{aA}$ & $4.15 \mathrm{aA}$ & $47.475 \mathrm{aA}$ & $111.756 \mathrm{aA}$ & $40.981 \mathrm{aA}$ & $79.12 \mathrm{aA}$ & $69.07 \mathrm{aA}$ & $34.82 \mathrm{aA}$ \\
Y91 & $3.24 \mathrm{aB}$ & $3.95 \mathrm{bA}$ & $3.02 \mathrm{bA}$ & $37.837 \mathrm{aA}$ & $81.550 \mathrm{aA}$ & $40.468 \mathrm{aA}$ & $62.64 \mathrm{bA}$ & $50.97 \mathrm{aA}$ & $20.23 \mathrm{bB}$ \\
Y10 & $2.96 \mathrm{aB}$ & $1.98 \mathrm{cA}$ & $2.66 \mathrm{aA}$ & $10.275 \mathrm{bA}$ & $9.912 \mathrm{bA}$ & $14.962 \mathrm{bA}$ & $17.12 \mathrm{cA}$ & $7.63 \mathrm{bA}$ & $7.45 \mathrm{cA}$ \\
Y80 & $1.54 \mathrm{aC}$ & $1.27 \mathrm{cA}$ & $0.96 \mathrm{bA}$ & $15.681 \mathrm{bA}$ & $21.487 \mathrm{bA}$ & $12.793 \mathrm{bA}$ & $27.59 \mathrm{cA}$ & $13.43 \mathrm{bB}$ & $6.58 \mathrm{cB}$ \\
Y62 & $2.70 \mathrm{aB}$ & $3.46 \mathrm{bA}$ & $4.22 \mathrm{aA}$ & $15.968 \mathrm{bA}$ & $12.031 \mathrm{bA}$ & $21.775 \mathrm{bA}$ & $26.61 \mathrm{cA}$ & $7.52 \mathrm{bB}$ & $10.89 \mathrm{cB}$ \\
Y93 & $3.26 \mathrm{aB}$ & $3.53 \mathrm{bA}$ & $1.89 \mathrm{aA}$ & $81.056 \mathrm{aA}$ & $69.281 \mathrm{aA}$ & $16.731 \mathrm{bB}$ & $139.12 \mathrm{aA}$ & $43.31 \mathrm{aB}$ & $17.52 \mathrm{cC}$ \\
Y50 & $1.03 \mathrm{aC}$ & $1.02 \mathrm{cA}$ & $0.72 \mathrm{bA}$ & $211 \mathrm{cA}$ & $712 \mathrm{cB}$ & $135 \mathrm{cB}$ & $4.76 \mathrm{dA}$ & $0.44 \mathrm{cA}$ & $2.17 \mathrm{cB}$ \\
\hline
\end{tabular}

Means followed by the same lowercase letter in the column or uppercase letter in the row do not differ statistically by the Scott-Knott test at $5 \%$ significance level. The original data were presented.

The Paluma cultivar, which is a known susceptible cultivar to M. enterolobii (GOMES et al., 2017), had similar result to some Psidium spp. accessions for all evaluated variables. The Y46 accession ( $P$. guineense) was significantly different from the Paluma cultivar (control) only at the highest inoculation level. The RF in the Y93 increased with increasing inoculation level, as well as for the Paluma cultivar. Some accessions were more susceptible to $M$ enterolobii than the Paluma cultivar, especially those from the $P$. guineense species, as found by Chiamolera et al. (2018). These accessions of $P$. guineense have genetic similarity of $81.4 \%$ with P. guajava (COSTA; SANTOS, 2013).

The RF in some Y50 plants was lower than 1.0 at the lowest inoculation levels (600 and 1,600 eggs $+\mathrm{J} 2$ ), and a plant was immune to the nematode at the inoculation level of 1,600 eggs $+\mathrm{J} 2$. Thus, Y50 presented the best characteristics of resistance to $M$. enterolobii; the nematode had the lowest mean number of eggs at the three levels of inoculation and presented RF between 0 and 17 (Tables 4 and 5).

$\mathrm{RF}$ is the most important factor to analyze the merit of an accession for resistance to $M$. enterolobii when considering the isolated means of variables. For example, two accessions (Y91 and Y93) were similar to the Paluma cultivar at the inoculation level of 600 eggs $+\mathrm{J} 2$; and Y46, Y91, and Y93 were similar to the Paluma cultivar at the inoculation level of 1,600 eggs $+\mathbf{J} 2$. Therefore, Y46 and Y93 were the most susceptible accessions to $M$. enterolobii. Burla et al. (2010) found positive correlation between inoculation level and RF, but still reported RF as the best variable for screening Psidium spp.; according to these authors, inoculation levels above 3,000 eggs may reduce $\mathrm{RF}$.

The highest RF at the inoculation levels of 1,600 (69.07) and 2,000 eggs + J2 (34.82) were found in the 'Paluma' cultivar. However, the mean RF of the nematode in the Paluma cultivar at the lowest inoculation level (600 eggs $+\mathrm{J} 2)$ was 79.12 (Table 3). These results confirm that high inoculation levels restrict nematode reproduction due to limitation of feeding sites for the establishment of $\mathrm{J} 2$ and development of females (BURLA et al., 2010).

The inoculation level had a significant effect on the mean RF; nine accessions presented significantly different $\mathrm{RF}$ in the three inoculation levels, and four (Y10, Y81, Y92, and Paluma) presented no significantly different RF (Table 3). This result confirms that the merit of an accession must be tested at different inoculation levels, including low inoculation levels. Some studies tested 
different inoculation levels, but including only high ranges, from 5,000 to 20,000 eggs per plant (CARNEIRO et al., 2007; MARTINS et al., 2013; FREITAS et al., 2014). Moreover, they consider the averages of each accession, and not the variation among plants within the same accession for morphological characters (SANTOS et al., 2014). Thus, analyzing the performance of individual plants and observing the nematode RF in each plant are necessary to assess the plants individually for inoculum multiplication on them (OOSTENBRINK, 1966).

The greatest nematode multiplication occurred at the lowest initial inoculation level, as observed by the nematode RF amplitude in plants of different accessions (Table 4). The highest RF ranged from 17 to 592 at the inoculation level of 600 eggs $+\mathrm{J} 2$. The highest RF at the level of 1,600 eggs $+\mathrm{J} 2$ ranged from 1.0 to 239 ; and the highest RF at inoculation level of 2,000 eggs $+\mathrm{J} 2$ ranged from 3.0 to 71. Martins et al. (2013) found average variation in counts of eggs and $\mathrm{J} 2$ of $M$. enterolobii from 181.67 to 428.246 , and RF ranging from 0.02 (ALU1) to 42.81 (A-PASTO) in plants inoculated with 20,000 eggs. Almeida et al. (2009) evaluated inoculation level of 4,000 eggs $+\mathrm{J} 2$ per guava plant and found RF ranging from 43.14 to 2.78 .

Table 4. Amplitude of reproduction factor of Meloidogyne enterolobii in Psidium spp. plants from different accessions with three inoculation levels (eggs $+\mathrm{J} 2)$.

\begin{tabular}{cccc}
\hline \multirow{2}{*}{ Accession } & \multicolumn{3}{c}{ Inoculation level (eggs + J2) } \\
\cline { 2 - 4 } & 600 & 1,600 & 2,000 \\
\hline Y81 & $3.0-105.0$ & $4.0-58.0$ & $0.1-39.0$ \\
Y48 & $14.0-215.0$ & $0.9-16.0$ & $0.6-34.0$ \\
Y105 & $5.0-32.0$ & $0.5-26.0$ & $4.0-13.0$ \\
Y40 & $20.0-103.0$ & $3.0-50.0$ & $1.0-13.0$ \\
Y92 & $10.0-117.0$ & $3.0-39.0$ & $11.0-44.0$ \\
Y46 & $50.0-143.0$ & $25.0-98.0$ & $9.0-19.0$ \\
Y91 & $16.0-165.0$ & $0.6-123.0$ & $6.0-48.0$ \\
Y10 & $1.5-39.0$ & $1.0-17.0$ & $0.9-14.0$ \\
Y80 & $12.0-63.0$ & $2.0-41.0$ & $3.0-26.0$ \\
Y62 & $9.0-48.0$ & $3.0-13.0$ & $4.0-24.0$ \\
Y93 & $35.8-592.2$ & $0.2-239.0$ & $1.0-43.5$ \\
Y50 & $0.9-17.0$ & $0.0-1.0$ & $0.2-3.0$ \\
'Paluma' & $37.3-198.8$ & $7.6-105.7$ & $16.6-71.3$ \\
\hline
\end{tabular}

The Paluma cultivar had similar RF to those of some more susceptible accessions of Psidium spp. (Y46, for example). In general, RF decreased with increasing inoculation levels, however, Y48, Y62, and Y50 had higher RF at the inoculation level of 1,600 eggs $+\mathrm{J} 2$ than at 2,000 eggs $+\mathrm{J} 2$ (Table 4). This result may be explained by the significant interaction found in the analysis of variance (Table 2). This denotes that the reduction in egg production in each plant, and consequently in the RF, could lead to false-positive results of resistance when using high inoculation levels, mainly by the restriction of infection sites for the J2 (BURLA et al., 2010).

Silva and Krasuski (2012) evaluated the reaction of Eugenia stipitata McVaugh (araçá-boi) and Psidium spp. (araçá) accessions to M. enterolobii and classified them as highly susceptible. This was also found in the present work for Psidium spp. accessions, especially when considering the nematode RF for the 'Paluma' cultivar, which was the susceptible control. It is shown by the RF in eight plants of Y93 and in seven of Paluma (Table 5); their RF varied among plants at the three inoculation levels. The highest absolute value of RF was found in the Y93, in which the nematode RF resulted in an increase in the final number of eggs $+\mathrm{J} 2$ of $592.2-$ fold the initial inoculation level of 600 eggs $+\mathrm{J} 2$ (plant 2). The Paluma cultivar had an increase of 198.8-fold the inoculation level of 600 eggs $+\mathrm{J} 2$ (plant 5) (Table 5). This variation in RF is found in most works with the Paluma cultivar, as described by Freitas et al. (2017), who found great variability in $R F$ for this cultivar $(R F=59-362)$.

These results denote the importance of using different inoculation levels to analyze the merit of an accession regarding its reaction to $M$. enterolobii. The best inoculation levels for screening Psidium spp. for resistance to $M$. enterolobii are from 500 to 2,000 eggs per plant, with evaluations between 135 and 180 days after inoculation (BURLA et al., 2010; MIRANDA et al., 2010); 135 days after inoculation was used in the present work. According to Burla et al. (2010) and Miranda et al. (2010), the use of higher inoculation levels $(5,000$ to 12,000 eggs per plant), usually found in the literature, may reduce the RF and show false-positive results, in which susceptible accessions will be classified as resistant. 
Different reactions of plants to the nematode were found in the different inoculation levels evaluated in the present study, even in those within the range recommended by Burla et al. (2010). Therefore, evaluating the individual reaction of plants to the nematode is important to avoid a high frequency of false-positive results due to the lack of establishment of $\mathrm{J} 2$ in the root system of young plants. Thus, the presence of false-positive results is probably much higher at higher inoculation levels.

Chiamolera (2015) evaluated the reaction of $P$. cattleianum, $P$. friedrichstalianum, E. stipitata, $P$. guajava var. minor Mattos, $P$. guineense, and $P$. acutangulum DC. inoculated with 3,000 eggs $+\mathrm{J} 2$ of $M$. enterolobii at 183 days after inoculation and found RF of 0.0 (immune plants), 0.0 and 0.05 (first three species), and 11.41, 17.91, and 6.65 (last three species), respectively. Thus, the mean RF in $E$. stipitata may indicate immune to susceptible plants, since no information about the replications was available. The present study showed variation among plants within each accession (Tables 4 and 5), which is little considered in other studies.

Miranda et al. (2012) found RF lower than 1.0 for three accessions of native guava trees, but did not mention the amplitude of the variation; their samples were collected in Bom Jesus de Itabapoana $(\mathrm{RF}=0.9)$, São João da Barra $(\mathrm{RF}=0.7)$, and Cachoeiras de Macacu $(\mathrm{RF}=0.4)$, RJ, Brazil. Silva et al. (2013) also found $R F<1.0$ in four accessions of guava; one sample was collected in Caparaó, $\mathrm{MG}$ $(\mathrm{RF}=0.5)$ and three in Iretama, $\mathrm{PR}(\mathrm{RF}=0.5,0.6$, and 0.6), Brazil. In the present study, Y50 presented resistant, immune, and susceptible plants to $M$. enterolobii, with RF ranging from 0 to 17.1 (Table 5).

Table 5. Reproduction factor (RF) of Meloidogyne enterolobii in Psidium spp. plants from the Y93 and Y50 accessions and Paluma cultivar under three inoculation levels, considering individual plants.

\begin{tabular}{|c|c|c|c|c|c|c|c|c|c|c|c|c|c|c|}
\hline & \multicolumn{14}{|c|}{ Inoculation level (eggs $+\mathrm{J} 2)$} \\
\hline & & 600 & 1,600 & 2,000 & & & 600 & 1,600 & 2,000 & & & 600 & 1,600 & 2,000 \\
\hline $\mathrm{AC}$ & $\mathrm{P}$ & & $\mathrm{RF}$ & & $\mathrm{AC}$ & $\mathrm{P}$ & & $\mathrm{RF}$ & & $\mathrm{AC}$ & $\mathrm{P}$ & & $\mathrm{RF}$ & \\
\hline \multirow{8}{*}{ Y93 } & 1 & 52.5 & 239.0 & 43.5 & \multirow{8}{*}{ 'Paluma' } & 1 & 37.3 & 99.1 & 16.6 & \multirow{8}{*}{ Y50 } & 1 & 6.6 & 0.5 & 3.5 \\
\hline & 2 & 592.2 & 30.9 & 7.2 & & 2 & 71.3 & 105.7 & 37.3 & & 2 & 17.1 & 1.2 & 2.0 \\
\hline & 3 & 87.8 & 18.4 & 14.8 & & 3 & 53.6 & 7.6 & 55.9 & & 3 & 2.2 & 0.1 & 0.2 \\
\hline & 4 & 56.9 & 13.6 & 22.6 & & 4 & 62.0 & 101.9 & 71.3 & & 4 & 7.0 & 0.1 & 2.9 \\
\hline & 5 & 134.2 & 13.1 & 2.8 & & 5 & 198.8 & 58.2 & 37.5 & & 5 & 1.2 & 0 & 1.2 \\
\hline & 6 & 52.0 & 11.6 & 18.2 & & 6 & 82.6 & 46.6 & 32.6 & & 6 & 0.9 & 0.1 & 0.8 \\
\hline & 7 & 101.6 & 19.8 & 23.0 & & 7 & 72.5 & 95.4 & 27.4 & & 7 & 2.6 & 0.6 & 3.8 \\
\hline & 8 & 35.8 & 0.2 & 1.0 & & - & - & - & - & & 8 & - & - & - \\
\hline
\end{tabular}

AC - accession; P-Plant; Dead plant.

Therefore, $P$. guajava has genes of resistance to $M$. enterolobii, although they may present a lower frequency in this species than in some araçá species (Psidium spp.), in which resistant and even immune plants are commonly found (MIRANDA et al., 2012). Considering estimated results of heritability of resistance to $M$. enterolobii in the $P$. guajava $\times P$. guineense hybrid, a dominant resistance model controlled by two genes with epistatic effects was found; in this case, the presence of only one dominant allele is the condition for the resistance found in this hybrid (COSTA; SANTOS; CASTRO, 2017).

Thus, the genotypes studied require reevaluations to confirm their resistance, and evaluating new accessions of native guava trees is necessary to confirm the existence of reliable sources of resistance. The confirmation of resistance in Psidium spp. accessions makes them strong candidates for rootstocks in guava nurseries in several producing regions, since the availability of resistant rootstocks to $M$. enterolobii has great demand by guava growers.

The presented and discussed results show variations between and within accessions when using univariate analysis and descriptive statistics. However, a more accurate result for this variation is obtained through clustering analysis. The 13 evaluated accessions were grouped into two groups through analysis of diversity by the Tocher's clustering method (CRUZ, 2013), considering the dissimilarity matrix obtained by combining root fresh weight, number of eggs, and reproduction factor data. Group I was formed by Y50; and group II by the $P$. guineense accessions and $P$. guajava cv. Paluma (Table 6), which presented different performances (Tables 6 and 7). 
Table 6. Clustering of 13 Psidium spp. accessions by the Tocher's clustering method, considering root fresh weight, number of eggs, and reproduction factor data.

\begin{tabular}{cc}
\hline Group & Accession \\
\hline I & Y50 \\
II & Y105, Y80, Y93, Y91, Y40, Y92, Y62, Y10, Y48, Y81, Y46'Paluma' \\
\hline
\end{tabular}

When the accessions were grouped by the UPGMA method, they also formed two groups, with only the Y50 accession in group I, and the other accessions in group II. However, two subgroups were formed, one by Y105 and Y80, and other by the other accessions (Figure 1). The latter formed two subgroups, one with six accessions (Y10, Y92, Y40, Y81, Y48, and Y62), and other with four (Y91, Y93, Y46, and 'Paluma'), which formed two subgroups, one with Y91 and Y93 and other with Y46 and 'Paluma' (Figure 1). These results denote diversity among the Psidium spp. accessions, and confirms the variation in the accession performances when considering the variables with means and individual values. In addition, the grouping by the UPGMA method was more informative than the Tocher's method to show the reaction of the accessions to the nematode. Souza et al. (2014) evaluated the genetic similarity of susceptible and resistant accessions to the nematode through RAPD (Random Amplification of Polymorphic DNA) markers and found resistant accessions allocated together with the susceptible ones.

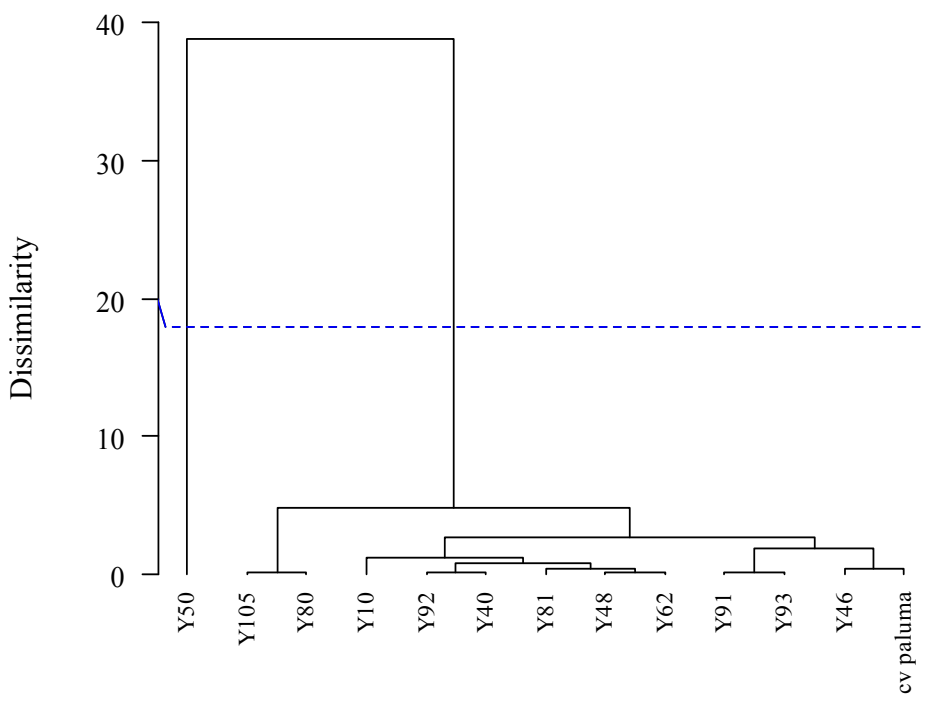

Figure 1. Clustering analysis of 13 Psidium spp. accessions by the unweighted pair group method with arithmetic mean (UPGMA).

An analysis on diversity excluding Y50 was carried out because it was very different from the others; the Tocher's method formed six groups (Table 7), and these groups were different from those formed by UPGMA (Figure 1), which formed two groups, one with Y40 and Y80 and other with the other accessions (Figure 2).

Table 7. Clustering analysis of 12 Psidium spp. accessions (excluding Y50) by the Tocher's method.

\begin{tabular}{cc}
\hline Groups & Accessions \\
\hline I & Y92, Y91 \\
II & Y62, Y40, Y80 \\
III & Y48, 'Paluma' \\
IV & Y81, Y46 \\
V & Y105, Y10 \\
VI & Y93 \\
\hline
\end{tabular}

The second subgroup was formed by three groups of accessions, one with Y81 and Y46, one with Y93, and one with Y62, Y48, and Paluma. The latter two formed subgroups that excluded Y62.
Therefore, the groups formed by the Tocher's method and the different groups and subgroups formed by the UPGMA show a reasonable agreement (Table 7 and Figure 2), with similar grouping of accessions 
(Y82 and Y91, Y40 and Y80, Y81 and Y46, Y105 and $\mathrm{Y} 10$, and $\mathrm{Y} 93$ ).

Y48 and 'Paluma' were grouped together by the UPGMA and Tocher's methods. Thus, the results of the multivariate analyses by the UPGMA and Tocher's methods without the Y50 accession were similar, as well as the performance of the accessions through the multivariate and univariate analyses. The presented and discussed data indicate that the use of low inoculation levels of $M$. enterolobii with increasing different inoculation levels is necessary when evaluating the merit of Psidium spp. accessions (guava or araçá) regarding their reaction to this nematode.

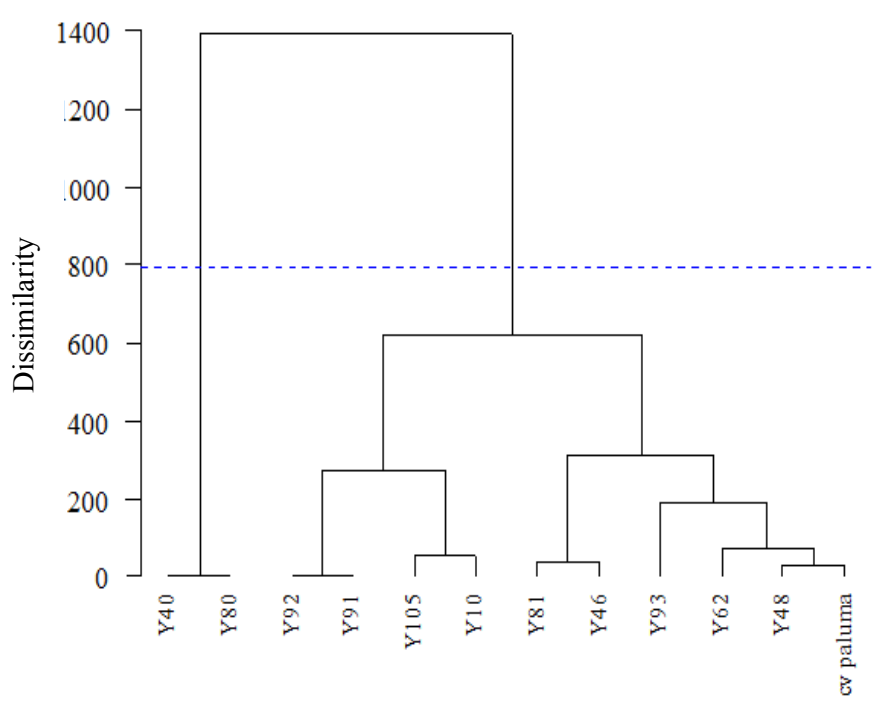

Figure 2. Clustering analysis of 12 Psidium spp. accessions (excluding Y50) by the unweighted pair group method with arithmetic mean (UPGMA). Cophenetic correlation coefficient $=0.75$.

However, studying the progeny of an accession is necessary to a more precise definition of its merit regarding reaction to $M$. enterolobii. Thus, all plants exposed to the nematode should be subjected to vegetative propagation to assess their progenies (ALTOÉ et al., 2011). This study is facilitated when using resistance sources found in $P$. guajava (MIRANDA et al., 2012, SILVA et al., 2013) or in native guava accessions that can be identified in new evaluations. This would benefit the vegetative propagation of plants, since propagation of araçá trees is more complex, requiring in vitro propagation (SANTOS, 2015). Studies on genetic inheritance of this character can be carried out with these procedures, using contrasting parental plants and fixed and segregating generations from the crossings; consequently, it will guarantee the identification of resistant rootstocks to $M$. enterolobii.

\section{CONCLUSIONS}

The reproduction factor (RF) of $M$. enterolobii reduced in some Psidium spp. accessions with increasing the inoculation levels, and increased in some of them at higher inoculation levels, which can generate false-positive results of resistance to this nematode. The Y50 accession had resistant and immune plants to $M$. enterolobii, denoting variability in the reaction to $M$. enterolobii within the Psidium genus. The RF results of the different accessions varied, as well as in the Paluma cultivar, which is reported in nematology studies as highly susceptible. The resistance of Psidium spp. accessions to $M$. enterolobii should be measured using different inoculation levels to confirm the resistance of these materials. The 13 different accessions evaluated in the present study presented distinct reactions to the nematode, considering their RF and the three studied inoculation levels.

\section{REFERENCES}

AGRIANUAL. Anuário da Agricultura Brasileira. 23. ed. São Paulo. FNP. Consultoria \& Agroinformativos, 2018. 503 p.

ALMEIDA, E. J. et al. Resistance of guava and araça to Meloidogyne mayaguensis. Pesquisa Agropecuária Brasileira, v. 44, n. 4, p. 421-423, 2009.

ALTOÉ, J. A. et al. Propagação de araçazeiro e goiabeira via miniestaquia de material juvenil. Bragantia, v. 70, n. 2, p. 312- 318, 2011.

AMAYA, D. R.; FARFAN, J. A. Nutrientes e substâncias bioativas da goiaba (Psidium guajava L.) e seus efeitos na saúde. In: NATALE, W. et al. (Eds.). Cultura da goiaba: do plantio à 
comercialização, Jaboticabal, SP: FCAV, 2009. v. 2, p. $595-634$.

BONETI, J. I. S.; FERRAZ, S. Modificação do método de Hussey e Barker para extração de ovos de Meloidogyne exigua em raízes de cafeeiro. Fitopatologia Brasileira, v. 6, n. 3, p. 553-553, 1981.

BURLA, R. S. et al. Comparação entre níveis de inóculo, época de avaliação e variáveis para seleção de Psidium spp. visando à resistência a Meloidogyne mayaguensis. Nematologia Brasileira, v. 34, n. 2, p. 82-90, 2010.

CARNEIRO, R. M. D. G. et al. Resistance to Meloidogyne mayaguensis in Psidium spp. accessions and their grafting compatibility with $P$. guajava cv. Paluma. Fitopatologia Brasileira, v. 32, n. 4, p. 281-284, 2007.

CASTRO, J. M. C. et al. Reproduction of the guava root-knot nematode in Psidium accesses. Comunicata Scientiae, v. 8, n. 1, p. 149-154, 2017.

CHIAMOLERA, F. M. Reação de araçazeiros a Meloidogyne enterolobii e enxertia de goiabeira 'PALUMA' em porta-enxertos resistentes. 2015. 61 f. Tese (Doutorado em Agronomia: Área de Concentração em Produção Vegetal) - Universidade do Estadual de Paulista, Faculdade de Ciências Agrárias e Veterinárias, Jaboticabal, 2015.

CHIAMOLERA, F. M. et al. Reaction of potential guava rootstocks to Meloidogyne enterolobii. Revista Ceres, v. 65, n. 3, p. 291-295, 2018.

COSTA, S. R.; SANTOS, C. A. F. Allelic database and divergence among Psidium accessions by using microsatellite markers. Genetics and Molecular Research, v. 12, n. 4, p. 6802-6812, 2013.

COSTA, S. R.; SANTOS, C. A. F.; CASTRO, J. M. C. Inheritance of resistance to Meloidogyne enterolobii in Psidium guajava $\mathrm{x} P$. guineense hybrid. European Journal of Plant Pathology, v. 148, n. 2, p. 405-411, 2017.

CRUZ, C. D. Genes: a software package for analysis in experimental statistics and quantitative genetics. Acta Scientiarum Agronomy, v. 35, n. 3, p. 271276, 2013.

CRUZ, C. D.; REGAZZI, A. J.; CARNEIRO, P. C. $\mathrm{S}$. Modelos biométricos aplicados ao melhoramento genético. 2. ed. Viçosa, MG: UFV, 2012. 514 p.

FRANZON, R. C. et al. Araçás do Gênero Psidium: Principais Espécies, Ocorrência,
Descrição e Usos. Planaltina, DF: Embrapa Cerrados, 2009, 48 p. (Documentos, 266).

FREITAS, V. M. et al. Host status of selected cultivated fruit crops to Meloidogyne enterolobii. European Journal of Plant Pathology, v. 148, n. 2, p. 307-319, 2017.

FREITAS, V. M. et al. Resistant accessions of wild Psidium spp. to Meloidogyne enterolobii and histological characterization of resistance. Plant Pathology, v. 63, n. 4, p. 738-746, 2014.

GOMES, V. M. et al. Guava decline: a complex disease involving Meloidogyne mayaguensis and Fusarium solani. Journal of Phytopathology, v. 159, n. 1, p. 45-50, 2011.

GOMES, V. M. et al. Inheritance of resistance to Meloidogyne enterolobii and individual selection in segregating populations of Psidium spp. European Journal of Plant Pathology, v. 148, n. 3, p. 699 708,2017

MANICA, I. et al. Fruticultura tropical: Goiaba. Porto Alegre, RS: Cinco Continentes, 2000. 373 p.

MARQUES, A. M. et al. Refinement of the karyological aspects of Psidium guineense (Swartz, 1788): a comparison with Psidium guajava (Linnaeus, 1753). Comparative Cytogenetics, v. 10, n. 1, p. 117, 2016.

MARTINS, L. S. S. et al. Parasitismo de Meloidogyne enterolobii em espécies de Myrtaceae. Revista Brasileira de Fruticultura, v. 35, n. 2, p. 477-484, 2013.

MIRANDA, G. B. et al. Assessment of methods and criteria for screening Psidium spp. for resistance to Meloidogyne enterolobii. Nematologia Brasileira, v. 34, n. 4, p. 211-219, 2010.

MIRANDA, G. B. et al. Avaliação de acessos de Psidium spp. quanto à resistência a Meloidogyne enterolobii. Bragantia, v. 71, n. 1, p. 52-58, 2012.

MOJENA, R. Hierarchical grouping methods and stopping rules: an evaluation. The Computer Journal, v. 20, n. 4, p. 359-363, 1977

MOURA, R.M.; RÉGIS, E. M. O. Reação de cultivares de feijoeiro comum (Phaseolus vulgaris) em relação ao parasitismo de Meloidogyne javanica e $M$. incognita (Nematoda: Heteroderidae). Nematologia Brasileira, v. 11, s/n., p. 215-225, 1987.

OOSTENBRINK, M. et al. Major characteristics of the relations between nematodes and plants. In: 
INTERNATIONAL SYMPOSIUM OF NEMATOLOGY. 8., 1968, Antibes, Anais...1966, p. 14.

PEREIRA, F. M.; NACHTIGAL, J. C. Melhoramento da Goiabeira. In: BRYCKENER, C. H. (Ed.). Melhoramento de Fruteiras Tropicais, Viçosa, MG: UFV, 2000, p. 267-289.

PEREIRA, K. C. et al. Development of guava cultivars parasitized by Meloidogyne enterolobii. Nematropica, v. 46, n. 1, p. 54-59, 2016.

SANTOS, M. A. C. et al. Diversidade genética entre acessos de araçá de diferentes municípios do Semiárido baiano. Revista Caatinga, v. 27, n. 2, p. 48-57, 2014.

SANTOS, M. A. C. Micropropagação de Psidium spp. 2015. 159 f. Tese (Doutorado em Agronomia: Área de concentração em Agricultura Tropical) Universidade Federal da Paraíba, Areia, 2015.

SÃO JOSÉ, A. R. et al. Cultivo de goiabeira no Brasil. In: PRIMER SIMPOSIO INTERNACIONAL DE LA GUAYABA, 1., 2003, Aguas Calientes. Memoria... 2003, p. 84-115.

SILVA, G. S.; KRASUSKI, A. I. Reação de algumas espécies frutíferas tropicais a Meloidogyne enterolobii. Nematologia Brasileira, v. 36, s/n., p. 83-86, 2012.

SILVA, S. N. et al. Avaliação a resistência de Psidium guajava L. ao Meloidogyne enterolobii In: CONGRESSO BRASILEIRO DE MELHORAMENTO DE PLANTAS, 7., 2013, Uberlândia, MG. Variedade Melhorada: A Força da Nossa Agicultura. Anais... Viçosa, MG: SBMP, 2013, p. $1375-1378$.

SOUZA, A. G. et al. Variabilidade genética de acessos de araçazeiro e goiabeira suscetíveis e resistentes a Meloidogyne enterolobii. Ciência Rural, v. 44, n. 5, p. 822-829, 2014. 